\title{
Case Study of Structural Reliability of Existing Building
}

\author{
Pēteris Drukisis", Līga Gaile, Vadims Goremikins \\ Kalı̧ Street 1, Riga, Latvia. Riga Technical University, Insitute of Structural Engineering and Reconstruction. \\ *Corresponding author: peteris.drukis@gmail.com, +371 29233300.
}

\begin{abstract}
Structural reliability of buildings has become an important issue after the collapse of a shopping centre in Riga 21.11.2013, caused the death of 54 people. The reliability of a building is the practice of designing, constructing, operating, maintaining and removing buildings in ways that ensure maintained health, ward suffered injuries or death due to use of the building. Evaluation and improvement of existing buildings is becoming more and more important.

For a large part of existing buildings, the design life has been reached or will be reached in the near future. The structures of these buildings need to be reassessed in order to find out whether the safety requirements are met. The safety requirements provided by the Eurocodes are a starting point for the assessment of safety. However, it would be uneconomical to require all existing buildings and structures to comply fully with these new codes and corresponding safety levels, therefore the assessment of existing buildings differs with each design situation. This case study describes the simple and practical procedure of determination of minimal reliability index $\beta$ of existing steel structures designed by different codes than Eurocodes and allows to reassess the actual safety level of different structural elements of existing buildings under design load.
\end{abstract}

Keywords: Structural reliability, existing buildings, assessment of safety, steel structures, partial factors, reliability index.

\section{INTRODUCTION}

Existing buildings in operation, if properly operated, are considered to be safe for people, even if these buildings are more than 100-year-old, or the so called heritage buildings [1]. However, due to technological progress, as well as changes in laws and regulations related to the integration in the European Union, the roles for both employees and maintenance staff regarding the use of buildings are becoming more and more strict. Existing buildings are designed according to the safety requirements of the decade they were built. However, the requirements of the respective safety level today are generally higher. New requirements have been introduced, the provision of which requires proper attention and resources from the building owner [2], and nowadays building safety requires special attention [3].

A lot of buildings depending on their time of construction in Latvia have different safety levels. Taking into consideration that users of the building expect the same level of safety, situations leading to severe accidents can occur. In Latvia there are buildings in operation, most of which were built more than 20 years ago in accordance with the Soviet building norms (SNiP) [4]. Furthermore, there are also buildings which were built before 2010 in accordance with national building norms (LBN) [5] whilst there are also buildings built during the last years already in accordance with the European
Union's construction standards or Eurocodes (EC) [6].

Furthermore, the operational duration of the building is longer than life-time of any other system and equipment in the building, which means that the building solutions, their operation and safety lag behind up-to-date technologies. If the condition of existing buildings will not be improved in accordance with contemporary requirements and safety level, the number of accidents occurring may rise.

Taking into consideration the above-mentioned circumstances, in the Construction Law [7], Article 21, Clause 4 the Parliament of Latvia has laid down the obligation of the owner of the building to provide proper maintenance of the building and its components during the operation thereof in the condition compliant with the essential requirements defined in the Construction Law, Article 9, Clause 4. These essential requirements are identical to the basic requirements defined by the European Parliament and EU Council Regulation Nr.305/2011 [8]:

- mechanical resistance and stability;

- safety in case of fire;

- hygiene, health and the environment;

- safety and accessibility in use;

- protection against noise;

- energy economy and heat retention;

- sustainable use of natural resources. 
In order to meet the above-stated requirements, the responsibility of the building owner is to make sure that:

- the building is safe for its users and building maintenance staff;

- the building is being properly maintained;

- essential risk factors are evaluated during the use of the building;

- relevant improvement measures are carried out in accordance with the results of technical surveys.

Therefore, it is extremely important for the owner of the building to get proper answers from engineers and technical auditors about the condition of existing structures [9-14]. Before the decision of refurbishment or disposal of a building not only economical or technical aspects are to be considered. An important factor due to the climate changes is sustainability [15]. That's why there are a lot of methods worldwide used for the grading of buildings based of sustainability criteria [16]. Also, improvement of energy efficiency of buildings gives a challenge to improve the condition of existing structures [17].

This paper is in the scope of the first essential requirement for buildings - mechanical resistance and stability. There are a lot of publications worldwide about the proper manner for retrofitting existing structures [18-23]. All those publications give researches of different studies of existing structures and they have one particular issue in common - the question of what is the right safety level of existing structures or the important question of "how safe is safe enough"? [24]

Reliability index $\beta$ is associated with the probability of failure in many publications. For example, in publications [25-27], it is shown as one of the main quantifiers of the reliability and it is also the main approach to reliability concepts in the structural codes of last decades.

An important reason to assess existing structures is the existence of a doubt concerning the actual reliability of a structure and its elements. In the case of retrofitting or repairing the structure, the set of the partial safety factors (a function of the reliability index $\beta$ ) per current design codes should be established.

This study proposes a simple procedure to derive the reliability index $\beta$ in line with Eurocode of the existing structure that originally was designed by earlier structural design codes. This makes it possible to comparable the reliability levels of existing structures to the target values of the current design practice.

The developed procedure is applied to the case study and the reliability index $\beta$ is derived for differently stressed elements of existing building roof truss.

\section{MATERIALS AND METHODS \\ A. Structural reliability in Eurocodes}

Generally, it is known that the target reliability levels are calibrated to the existing practice that is proven to be satisfactory and partly introduced through the structural design codes. The most common method is the partial factor design method where partial safety factors are a function of the reliability level [28]. Eurocode uses two safety factors performing the standard design procedures. These are safety factors for the material property $\gamma_{\mathrm{m}}$ and safety factor for loads $\gamma_{\mathrm{f}}$. A simple method to obtain the relevant partial factor $\gamma_{\mathrm{f}}$ is to divide the design value of a variable action $Q_{d}$ by its representative or characteristic value $\mathrm{Q}_{\mathrm{k}}$. Similarly, could be obtained material partial factor $\gamma_{\mathrm{m}}$. The normal distribution is normally used for characteristic and design values of material properties [29] and for permanent loads G, but for snow loads Gumbel redistribution is used [29] (see Table 1).

Table 1

\begin{tabular}{lll}
\hline Value & Redistribution & Equation \\
\hline$R_{k}$ & Normal & $\mu_{R} \cdot \exp \left(-1,645 V_{R}\right)$ \\
$R_{d}$ & Normal & $\mu_{R} \cdot \exp \left(-\alpha_{R} \beta_{d} V_{R}\right)$ \\
$G_{k}$ & Normal & $\mu_{G}$ \\
$G_{d}$ & Normal & $\mu_{G}\left(1+0,7 \beta_{d} V_{G}\right)$ \\
$Q_{k}$ & Gumbel & $\mu_{Q}\left(1-V_{Q}(0,45+\right.$ \\
& $+0,78 \ln (-\ln (0,98))))$ \\
$Q_{d}$ & Gumbel & $\mu_{Q}\left(1-V_{Q}(0,45+0,78\right.$ \\
$\gamma_{R}=\frac{\exp \left(-1,645 V_{R}\right)}{\exp \left(-\alpha_{R} \beta_{d} V_{R}\right)}$ & $\left.\cdot \ln \left(-\ln \left(\Phi^{-1}\left(\alpha_{E} \beta\right)\right)\right)\right)$ \\
$\gamma_{G}=\left(1+0,7 \beta_{d} V_{G}\right)$ & \\
$\gamma_{Q}=\frac{1-V_{Q}\left(0,45+0,78 \cdot \ln \left(-\ln \left(\Phi^{-1}\left(\alpha_{E} \beta\right)\right)\right)\right)}{1-V_{Q}(0,45+0,78 \ln (-\ln (0,98)))}$
\end{tabular}

In these expressions $\mu, \sigma$ and $\mathrm{V}$ are, respectively, the mean value, the standard deviation and the coefficient of variation of a given variable, $\alpha$ is FORM (First Order Reliability Method) sensitivity factor and $\beta$ is reliability index, $\Phi^{-1}$ is failure probability function; $\gamma$ is relevant partial factor.

\section{B. Determination of reliability index}

The newly developed simple procedure of determination of reliability index $\beta$ for existing structures is presented via case study. For the case study a steel roof truss and one supporting beam of an existing building in Liepaja, Latvia is chosen. The span of the truss is $32 \mathrm{~m}$, but the span of the simply supported beam is $10,8 \mathrm{~m}$. The configuration of the truss is presented in the Figure 1. 


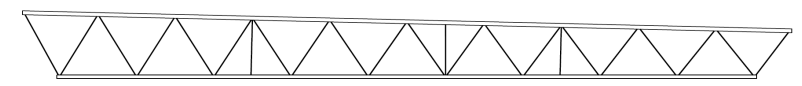

Fig. 1. The geometry of the roof truss.

The roof truss is loaded by the permanent load and snow load uniformly distributed over the truss length. Wind load influence has not been considered as it produces negligible internal forces in truss elements. The simply supported beam supports the truss and is loaded in three-point bending. All cross sections of truss elements are square hollow sections, but the beam is made of one I section. The three most loaded elements of the truss under different loading conditions are selected for the analysis: the element of the top chord under compression and bending, truss compression diagonal and bottom chord under tension.

Before starting to determine the reliability index $\beta$ it is recommended to calculate the utilization factor $U$ (design effect / characteristic effect) of each element according to the design codes that were valid during building construction time (SNiP system [30]).

When calculating according to the SNiP structural design code three safety partial factors should be used in this case. These are - the safety factor for material properties $\gamma_{\mathrm{m}}$ equal to 1,025 , safety factor $\gamma_{\mathrm{c}}$ that takes into account exploitation conditions and is equal to 1 for elements in compression, compression and bending, and bending only. For the tension elements, it is equal to 0,95 . The third safety factor for loads $\gamma_{\mathrm{f}}$ equal to 1,6 for snow loads (on light roofs) and 1,3 for permanent loads excluding steel self-weight when it is 1,05 .

Applied loads on trusses for the case study are presented in Table 2 .

\begin{tabular}{lccc}
\multicolumn{4}{c}{ Table 2. } \\
\hline $\begin{array}{c}\text { Applied } \\
\text { load }\end{array}$ & $\begin{array}{c}\text { According to } \\
\text { SNiP } \\
\text { in Liepaja, } \\
\mathrm{kN} / \mathrm{m}\end{array}$ & $\begin{array}{c}\text { According to } \\
\text { SNiP } \\
\text { in Riga, } \mathrm{kN} / \mathrm{m}\end{array}$ & $\begin{array}{r}\text { According to } \\
\text { Eurocode NA } \\
\text { in Liepaja and } \\
\text { Riga, } \mathrm{kN} / \mathrm{m}\end{array}$ \\
\hline$G_{k}$ & 2,4 & 2,4 & 2,4 \\
$G_{d}$ & 2,8 & 2,8 & $\mathrm{~N} / \mathrm{A}$ \\
$Q_{k}$ & 2,7 & 3,8 & 5,4 \\
$Q_{d}$ & 4,3 & 6,1 & $\mathrm{~N} / \mathrm{A}$ \\
$\begin{array}{l}\mathrm{G} \text { and Q is permanent and variable (snow) load and subscripts } \\
\text { denote whether it is characteristic or design load. } \\
\text { N/A - not applied (calculated later from reliability index } \beta \text { ) }\end{array}$ \\
\hline
\end{tabular}

For the given example, the maximum design force in the tension chord (loading is applied according to (SNiP for Liepaja) is $401.9 \mathrm{kN}$ and calculated design resistance of SHS 140x140x4 ( $\left.\mathrm{R}_{\mathrm{y}}=335 \mathrm{MPa}\right)$ (according to $\mathrm{SNiP}$ ) is $679 \mathrm{kN}$ makes utilization factor $\mathrm{U}=59 \%$. This utilization factor is just information needed to assess stress level in the member. Correspondingly it is possible for the element under consideration to determine reliability index $\beta$ by using the equations given in Table 1 when the utilization factor $\mathrm{U}$ is near $100 \%$. This implies calculating the design loads and resistances according to general Eurocode design procedures. For the same element SHS $140 x 140 x 4\left(f_{y}=345 \mathrm{MPa}\right)$ according to Eurocode design load is $633,2 \mathrm{kN}$ and design resistance is 637,99 . Therefore the utilization factor is $99,2 \%$. This is reached when partial factors corresponding to $\beta=4,3$ is used. Two partial safety factors are used performing reliability design - the safety factor for material resistance $\gamma_{\mathrm{R}}$ and load partial safety factor $\gamma_{\mathrm{m}}$.

The first step is to determine the required cross section according to the SNIP when the utilization factor $U$ is also about $100 \%$. Then for the tension element in consideration, the cross section of the element should be reduced to SHS 90x90x4.

Now in the next step it is possible to obtain the reliability index $\beta$ using the same Eurocode procedure as before. Eurocode characteristic loads should be applied iteratively and $\beta$ could be found when the utilization factor $U$ is about $100 \%$. For the previously discussed element $\beta$ is found to be 2,5, which corresponds to probability of failure equal to $0.621 \%$.

The predetermined reliability indexes $\beta$ could be compared with target reliability indexes depending on consequence classes according to EN1990 ( $\beta=3.8$ for building under consideration). In the case of the tension member of roof truss in Liepaja, the safety level difference is $34 \%$ which could be regarded as considerable. The corresponding probability of failure will increase from $0.0072 \%$ to $0.62 \%$, respectively.

The summary of the proposed procedure of the determination of minimal reliability index $\beta$ for structures that are designed in accordance to different structural codes than Eurocodes is presented in Figure 2.

In this case-study, the following coefficients of variation were used: for snow load $\mathrm{V}_{\mathrm{Q}}=0,6$; for permanent load $\mathrm{V}_{\mathrm{G}=0,1}$ and for material properties $\mathrm{V}_{\mathrm{R}}=0,08$. The sensitivity factors chosen according to ISO 2394 [31] and equal to $\alpha_{\mathrm{Q}}=0,7$ for snow load, $\alpha_{G}=-0,7$ for permanent load and $\alpha_{R}=0,8$ for material properties.

\section{RESULTS AND DISCUSSION}

A. Minimal reliability index of existing structure designed by different codes than Eurocodes

Table 3 to 6 presents results of the case study obtained by the simple and practical procedure developed as the result of the current research. Results are presented per element phenomena.

The calculated actual reliability index $\beta$ for the analyzed elements of the case-study under Eurocode design loads and design resistances varies from 4,3 to 3,3 . The reliability index $\beta$ target value according to Eurocode for a 50-year design life and 50-year reference period of variable loads for buildings with reliability class $\mathrm{RC} 2$ is 3,8 . 
The calculated theoretical reliability index $\beta$ for the analyzed elements with a utilization factor $\mathrm{U}=100 \%$ according to SNiP design loads and design resistances in city Liepaja varies from 2,5 to 2,8 , but in Riga from 3,2 to 3,5.

\section{B. Discussion}

Although in general the load bearing capacity of analysed elements is higher when using the Eurocode design system due to the utilizing the plastic geometrical properties of cross sections, the reliability index $\beta$ for elements is considerably lower when using the SNIP design code system. Mostly it is because the design loads in the Eurocode system are noticeably higher. Moreover, it has been discovered that the safety level varies among the region of the country considered since the climatic snow load maps are not the same for the SNIP and Eurocode systems.

The target reliability index $\beta$ given in EN 1990 [28] is provided for new buildings. For the existing structure, target reliability levels can be modified in respect to the current code values assumed for new structures [32]. These modifications are still under discussion in the industry and the next researches will examine the context of geographical location and national traditions.

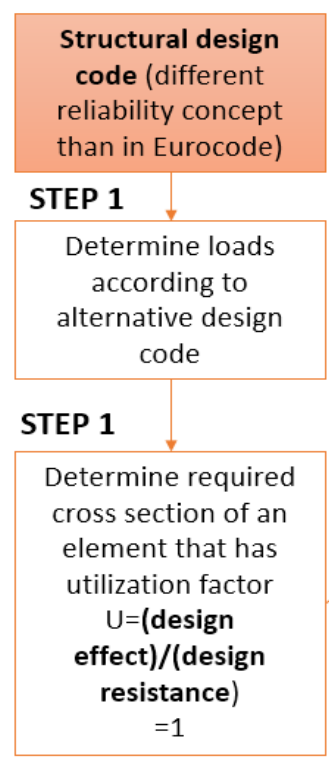

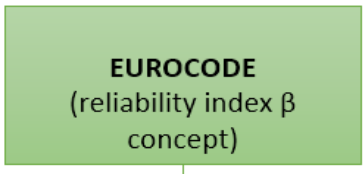

\section{STEP 2}

Determine characteristic load effects according to Eurocode $\left(\mathrm{E}_{\mathrm{G}, \mathrm{k}}, \mathrm{E}_{\mathrm{Q}, \mathrm{k}}\right)$

\section{STEP 4}

Determine characteristic resistance according to Eurocode $\left(R_{k}\right)$

Fig. 2. Determination procedure of minimal reliability index $\beta$ of existing structure designed by different codes than EC

Table 3.

Element of truss top chord under compression and bending

\begin{tabular}{|c|c|c|c|c|c|c|}
\hline \multirow{2}{*}{ City } & \multirow{2}{*}{\multicolumn{2}{|c|}{$\begin{array}{l}\text { As built } \\
\text { Liepaja }\end{array}$}} & \multicolumn{4}{|c|}{ If designed with $\sim 100 \%$ utilization } \\
\hline & & & \multicolumn{2}{|c|}{ Liepaja } & \multicolumn{2}{|c|}{ Riga } \\
\hline Code & SNiP & Eurocode & SNiP & Eurocode & SNiP & Eurocode \\
\hline$\beta$ & - & 3.8 & - & 2.6 & - & 3.2 \\
\hline$\gamma_{Q}$ & - & 1.30 & - & 0.90 & - & 1.09 \\
\hline$\gamma_{\mathrm{G}}$ & - & 1.27 & - & 1.18 & - & 1.22 \\
\hline$\gamma_{\mathrm{R}}$ & - & 1.12 & - & 1.04 & - & 1.08 \\
\hline Internal loads & $\mathrm{N}_{\mathrm{d}}=388 \mathrm{kN}$ & $\mathrm{N}_{\mathrm{Ed}}=546.9 \mathrm{kN}$ & $\mathrm{N}_{\mathrm{d}}=388 \mathrm{kN}$ & $\mathrm{N}_{\mathrm{Ed}}=418.1 \mathrm{kN}$ & $\mathrm{N}_{\mathrm{d}}=483 \mathrm{kN}$ & $\mathrm{N}_{\mathrm{Ed}}=478.4 \mathrm{kN}$ \\
\hline & $\mathrm{M}_{\mathrm{d}}=4.89$ & $\mathrm{M}_{\mathrm{s}, \mathrm{Ed}}=6.9 \mathrm{kNm}$ & $\mathrm{M}_{\mathrm{d}}=4.89 \mathrm{kNm}$ & $\mathrm{M}_{\mathrm{s}, \mathrm{Ed}}=5.3 \mathrm{kNm}$ & $\mathrm{M}_{\mathrm{d}}=6.08 \mathrm{kNm}$ & $\mathrm{M}_{\mathrm{s}, \mathrm{Ed}}=6.0 \mathrm{kNm}$ \\
\hline & $\mathrm{kNm}$ & $\mathrm{M}_{\mathrm{h}, \mathrm{Ed}}=8.6 \mathrm{kNm}$ & & $\mathrm{M}_{\mathrm{h}, \mathrm{Ed}}=6.6 \mathrm{kNm}$ & & $\mathrm{M}_{\mathrm{h}, \mathrm{Ed}}=7.5 \mathrm{kNm}$ \\
\hline Utilization factor $\mathrm{U}$ & $68 \%$ & $98 \%$ & $98 \%$ & $100 \%$ & $95 \%$ & $99 \%$ \\
\hline Cross-section & \multicolumn{2}{|c|}{$\square 160 \times 160 \times 4$} & \multicolumn{2}{|c|}{$\square 130 \times 130 \times 4$} & \multicolumn{2}{|c|}{$\square 150 \times 150 \times 4$} \\
\hline
\end{tabular}

Table 4 .

Element of truss bottom chord under tension

\begin{tabular}{|c|c|c|c|c|c|c|}
\hline \multirow{2}{*}{ City } & \multirow{2}{*}{\multicolumn{2}{|c|}{$\begin{array}{l}\text { As built } \\
\text { Liepaja }\end{array}$}} & \multicolumn{4}{|c|}{ If designed with $\sim 100 \%$ utilization } \\
\hline & & & \multicolumn{2}{|c|}{ Liepaja } & \multicolumn{2}{|c|}{ Riga } \\
\hline Code & SNiP & Eurocode & SNiP & Eurocode & SNiP & Eurocode \\
\hline$\beta$ & - & 4.3 & - & 2.5 & - & 3.2 \\
\hline$\gamma_{Q}$ & - & 1.50 & - & 0.87 & - & 1.09 \\
\hline$\gamma_{\mathrm{G}}$ & - & 1.30 & - & 1.18 & - & 1.22 \\
\hline$\gamma_{\mathrm{R}}$ & - & 1.15 & - & 1.03 & - & 1.08 \\
\hline Internal loads & $\begin{array}{c}\mathrm{N}_{\mathrm{d}}=401.9 \\
\mathrm{kN}\end{array}$ & $\mathrm{N}_{\mathrm{Ed}}=633.2 \mathrm{kN}$ & $\mathrm{N}_{\mathrm{d}}=401.9 \mathrm{kN}$ & $\mathrm{N}_{\mathrm{Ed}}=424.2 \mathrm{kN}$ & $\mathrm{N}_{\mathrm{d}}=500 \mathrm{kN}$ & $\mathrm{N}_{\mathrm{Ed}}=496.3 \mathrm{kN}$ \\
\hline Utilization factor $\mathrm{U}$ & $59 \%$ & $99.2 \%$ & $95 \%$ & $98 \%$ & $96 \%$ & $97.5 \%$ \\
\hline Cross-section & \multicolumn{2}{|c|}{$\square 140 \times 140 \times 4$} & \multicolumn{2}{|c|}{$\square 90 \times 90 \times 4$} & \multicolumn{2}{|c|}{$\square 90 \times 90 \times 5$} \\
\hline
\end{tabular}


Environment. Technology. Resources, Rezekne, Latvia Proceedings of the $11^{\text {th }}$ International Scientific and Practical Conference. Volume III, 47-52

Table 5.

Compressed element of truss diagonal

\begin{tabular}{|c|c|c|c|c|c|c|}
\hline \multirow{2}{*}{ City } & \multirow{2}{*}{\multicolumn{2}{|c|}{$\begin{array}{l}\text { As built } \\
\text { Liepaja }\end{array}$}} & \multicolumn{4}{|c|}{ If designed with $100 \%$ utilization } \\
\hline & & & \multicolumn{2}{|c|}{ Liepaja } & \multicolumn{2}{|c|}{ Riga } \\
\hline Code & $\mathrm{SNiP}$ & Eurocode & SNiP & Eurocode & SNiP & Eurocode \\
\hline$\beta$ & - & 3.3 & - & 2.8 & - & 3.3 \\
\hline$\gamma_{\mathrm{Q}}$ & - & 1.12 & - & 0.96 & - & 1.12 \\
\hline$\gamma_{\mathrm{G}}$ & - & 1.23 & - & 1.20 & - & 1.23 \\
\hline$\gamma_{R}$ & - & 1.08 & - & 1.05 & - & 1.08 \\
\hline Internal loads & $\begin{array}{c}\mathrm{N}_{\mathrm{d}}=99.2 \\
\mathrm{kN}\end{array}$ & $\mathrm{N}_{\mathrm{Ed}}=125.2 \mathrm{kN}$ & $\mathrm{N}_{\mathrm{d}}=99.2 \mathrm{kN}$ & $\mathrm{N}_{\mathrm{Ed}}=111.9 \mathrm{kN}$ & $\mathrm{N}_{\mathrm{d}}=123.4 \mathrm{kN}$ & $\mathrm{N}_{\mathrm{Ed}}=125.2 \mathrm{kN}$ \\
\hline Utilization factor $U$ & $81 \%$ & $98 \%$ & $95 \%$ & $98 \%$ & $100 \%$ & $97.5 \%$ \\
\hline Cross-section & \multicolumn{2}{|c|}{$\frac{1}{\square 80 \times 80 \times 3}$} & \multicolumn{2}{|c|}{$\square 80 \times 80 \times 2.5$} & \multicolumn{2}{|c|}{$\frac{1}{\square 80 \times 80 \times 3}$} \\
\hline
\end{tabular}

Table 6 .

Beam in bending

\begin{tabular}{|c|c|c|c|c|c|c|}
\hline \multirow{2}{*}{ City } & \multirow{2}{*}{\multicolumn{2}{|c|}{$\begin{array}{l}\text { As built } \\
\text { Liepaja }\end{array}$}} & \multicolumn{4}{|c|}{ If designed with $100 \%$ utilization } \\
\hline & & & \multicolumn{2}{|c|}{ Liepaja } & \multicolumn{2}{|c|}{ Riga } \\
\hline Code & SNiP & Eurocode & SNiP & Eurocode & SNiP & Eurocode \\
\hline$\beta$ & - & 3.5 & - & 2.7 & - & 3.5 \\
\hline$\gamma_{Q}$ & - & 1.19 & - & 0.93 & - & 1.19 \\
\hline$\gamma_{\mathrm{G}}$ & - & 1.25 & - & 1.19 & - & 1.25 \\
\hline$\gamma_{R}$ & - & 1.10 & - & 1.04 & - & 1.10 \\
\hline Internal loads & $\begin{array}{c}\mathrm{M}_{\mathrm{d}}=589 \\
\mathrm{kNm}\end{array}$ & $\begin{array}{c}\mathrm{M}_{\mathrm{Ed}}=777.5 \\
\mathrm{kNm}\end{array}$ & $\mathrm{M}_{\mathrm{d}}=589 \mathrm{kNm}$ & $\mathrm{M}_{\mathrm{Ed}}=650 \mathrm{kNm}$ & $\mathrm{M}_{\mathrm{d}}=732 \mathrm{kNm}$ & $\mathrm{M}_{\mathrm{Ed}}=777 \mathrm{kNm}$ \\
\hline Utilization factor $U$ & $80 \%$ & $99 \%$ & $100 \%$ & $98 \%$ & $99 \%$ & $99 \%$ \\
\hline Cross-section & \multicolumn{2}{|c|}{ IPE600 } & \multicolumn{2}{|c|}{ IPE550 } & \multicolumn{2}{|c|}{ IPE600 } \\
\hline
\end{tabular}

\section{CONCLUSION}

The developed simple and practical procedure of determination of minimal reliability index $\beta$ of existing structure designed by different codes than Eurocodes allows to assess the actual safety level of different structural elements of buildings. It is very important to Latvia, as most of the existing buildings are designed to different structural codes and actual safety level generally is unknown. Therefore, often arises the question do some parts of buildings needs to be strengthened to reach the safety level of the current design codes in force.

The case study of the existing building with light weight roof in the city Liepaja and Riga revealed that the reliability index $\beta$ and therefore safety level of elements varies even between the regions of Latvia. It is since climatic snow maps are changed relatively recently.

The reliability index $\beta$ of the structural elements depending on the phenomena varies in limits of 2,5 to 2,8 for Liepaja and 3,2 to 3,5 for Riga. That are lower values than target reliability index $\beta$ set in the ISO 13822 [33] for buildings with medium consequences of failure and minimum standard period for safety 50 years. This target safety level for existing buildings varies from different aspects and will be analysed in the next researches to look for the optimal ways to reduce it as most of the existing building elements seems to fall below the value denoted in current ISO standard.

\section{V.REFERENCES}

[1] Dalia Abdelaziz Elsorady, Assessment of the compatibility of new uses for heritage buildings; Journal of Cultural Heritage 15 (2014) 511-521.

[2] Simone Ferrari, Federica Zagarella, Costs assessment for building renovation cost-optimal analysis Energy Procedia 78 (2015) $2378-2384$.
[3] Francesca Cappelletti, Tiziano Dalla Mora, Fabio Peron, Piercarlo Romagnoni, Paolo Ruggeri, Building renovation: which kind of guidelines could be proposed for policy makers and professional owners? Energy Procedia 78 (2015) 2366 2371.

[4] National Construction Programme [online]. Riga, Cabinet of Ministers. 2002. [cited 30 August 2002]. Available, from Internet: http://likumi.lv/doc.php?id=65990u (in Latvian).

[5] The Latvian Eurocode National Implementation plan for 2013-2014 years [online]. Riga, Cabinet of Ministers. 2012. [cited 10 January 2013]. Available from Internet: http://www.likumi.lv/doc.php?id=247907 (in Latvian).

[6] Liga Gaile, Andina Sprince, Leonids Pakrastinsh, Specific Challenges of Adopting Eurocodes in Latvia, Procedia Engineering 57 (2013) $294-301$.

[7] Construction Law [online]. Riga, Latvian Parliament, 2013 [cited 30 July 2013]. Available, from Internet: http://likumi.lv/doc.php?id=258572 (in Latvian).

[8] Regulation (EU) No 305/2011 of the European Parliament and of the Council of 9 March 2011 laying down harmonised conditions for the marketing of construction products and repealing Council Directive 89/106/EEC, Strasbourg, 9 March 2011. Available, from Internet: http://eurlex.europa.eu/legalcontent/EN/TXT/?uri=CELEX:32011R0305

[9] Bertram KühnAssessment of existing steel structures Recommendations for estimation of the remaining fatigue life Procedia Engineering 66 (2013) 3 - 11

[10] Dir.u.Prof.Dr.W.Rücker, Dipl.-Ing. F.Hille, Dipl.Ing.R.Rohrmann, F08a Guideline for the Assessment of Existing Structures, Federal Institute of Materials Research and Testing (BAM), Samco 2006;

[11] Dimitris Diamantidis; Paolo Bazzurro Safety acceptance criteria for existing structures, University of Applied Sciences, Regensburg

[12] M.Sykora, M.Holicky, Target reliability levels for the assessment of existing structures

[13] Quanwang Li_, Bruce R. Ellingwood, Damage inspection and vulnerability analysis of existing buildings with steel moment-resisting frames, Engineering Structures 30 (2008) 338-351

[14] Daniel W.M. Chan, Tracy N.Y. Choi, Difficulties in executing the Mandatory Building Inspection Scheme (MBIS) for existing private buildings in Hong Kong, Habitat International 48 (2015) 97-105. 
[15] Sophie I.Hallstedt Sustainability criteria and sustainability compliance index for decision support in product development, Journal of Cleaner production 140 (2017) 251266

[16] Raji Banani, Maria.M.Vahdati, Mehdi Shahrestani, Derek Clements-Croome, The development of building assessment criteria framework for sustainable non-residental buildings in Saudi Arabia; Sustainable Cities and Society 26 (2016) 289305 ;

[17] Zhenjun Ma, Paul Cooper, Daniel Daly, Laia Ledo, Existing building retrofits: Methodology and state-of-the-art; Energy and Buildings 55 (2012) 889-902

[18] Nuno Pereira, Xavier Romão; Assessment of the concrete strength in existing buildings using a finite population approach, Construction and Building Materials 110 (2016) 106-116.

[19] Szigeti, F. and Davis, G, Using the ASTM/ANSI Standards for Whole Building Functionality and Serviceability for major asset and portfolio decisions, CIB World Building Congress, April 2001, Wellington, New Zealand, Paper: CLI 16.

[20] Ki-Uhn Ahn, Deuk-Woo Kim, Young-Jin Kim, Cheol-Soo Park, In-Han Kim, Gaussian Process model for control of an existing building, Energy Procedia 78 ( 2015 ) 2136 - 2141.

[21] B. Radhika, C.S. Manohar, Reliability models for existing structures based on dynamic state estimation and data based asymptotic extreme value analysis, Probabilistic Engineering Mechanics 25 (2010) 393_405

[22] Wei Gao, Chongmin Song, Francis Tin-Loi, Probabilistic interval analysis for structures with uncertainty, Structural Safety 32 (2010) 191-199.

[23] Starr, Ch.: "Social Benefit versus Technological Risk"; Science, Vol. 165, No. 19, S. 1232, 1969
[24] R.D.J.M.Steenbergen, A.C.W.M.Vrouwenvelder; Safety philosophy for existing structures and partial factors for traffic loads on bridges, TNO, Built Environment and Geosciences, Delft, the Nederlands, HERON Vol.55 (2010) No.2 125-139

[25] Dr.Nico P.M.Scholten, Prof.Ton.C.W.M Vrouwenvelder, Eurocodes and structural safety of the existing buildings considering the publication of the Dutch NEN 8700, $4^{\text {th }}$ International Conference Civil Engineering 13, Proceeding Part II, Building and Renovation

[26] V.V.Nadolskiy, M.Sykora, M.Holicky, Comparison of Reliability levels provided by the Eurocodes and standards of the Republic of Belarus, Vestnik MGSU, 2013

[27] Paul Luechinger; Juerg Fischer, New European Technical Rules for the assessment and retrofitting of existing structures, European Commission, Joint Research Centre, Institute for the Protection and Security of the Citizen, 2015

[28] EN 1990:2002 Eurocode: Basis of structural design

[29] Implementation of Eurocodes. Handbook 2. Reliability background. Guide to basis of structural reliability and risk engineering related to Eurocodes, supplemented by practical examples. Leonardo da Vinci pilot project CZ/02/B/F/PP134007, Prague 10, 2005

[30] SNIP 2.01.07-85* Building regulations. Loads and actions. USSR State Building. 1987.

[31] ISO 2394: 2015 General principles on reliability for structures

[32] CEN/TC/250/WG2 Assessment and retrofitting of existing structures, Bases. Report N2032, 2014

[33] ISO 13822:2010 Bases for design of structures - Assessment of existing structures 